\author{
Afonina Olena \\ Doctor in Art Studies, \\ Associate Professor of National Academy of Manafe- \\ rial Staff of Culture and Arts \\ ORCID 0000-0003-1627-6362 \\ Aolena7@gmail.com
}

\title{
THE ARTISTIC IMAGE IN THE CONTEXT OF CULTUROLOGICAL HERMENEUTICS
}

The purpose of the research to reveal the features of the interpretation of the artistic image in the works of contemporary art in the context of culturological hermeneutics. The methodology of this work is based on interdisciplinary approach - «culturological hermeneutics» enriched by the achievements of such joint methodologies as analytical psychology, structuralism, culture morphology, etc. Scientific novelty of this work lies in the analysis of the artistic image in works of contemporary art in the context of culturological hermeneutics. Conclusions. Based on the analysis of works of contemporary art, it is revealed that the interpretation of the artistic image remains open and inexhaustible, according to the principles of hermeneutics. Each interpreter will have his own approach to translating the content of the new text, which in turn will be another interpretation of the original text in art criticism. It is substantiated that the author's experience has primary importance for revealing the artistic image and content of the work. Disclosure of the artistic image is associated with the perception and therefore includes the principles of the receptive aesthetics. porary art.

Key words: artistic image, culturological hermeneutics, psychology, structuralism, post-structuralism, contem-

Афоніна Олена Сталівна, доктор мистецтвознавства, доцент кафедри естрадного виконавства Національної академії керівних кадрів культури і мистеитв

Художній образ у контексті культурологічної герменевтики

Мета - виявити особливості інтерпретації художнього образу в творах сучасного мистецтва в контексті культурологічної герменевтики. Методологія роботи заснована на міждисциплінарному підході «культурологічної герменевтики», збагаченому методами аналітичної психології, структуралізму, постструктуралізму. Наукова новизна роботи полягає в аналізі художнього образу в творах сучасного мистецтва в контексті культурологічної герменевтики. Висновки. Грунтуючись на аналізі творів сучасного мистецтва, обгрунтовано, тлумачення художнього образу має незамкнутість і невичерпність інтерпретацій відповідно до принципів герменевтики. У кожного інтерпретатора буде власний підхід до змісту як нового тексту, так і першоджерела. На прикладах тлумачення художніх образів в творах сучасного мистецтва підтверджено, що досвід автора має першорядне значення. Розкриття художнього образу пов'язане з психологією сприйняттям і тому включає в себе естетичні критерії.

Ключові слова: художній образ, культурологічна герменевтика, психологія, структуралізм, постструктуралізм, сучасне мистецтво.

Афонина Елена Стальевна, доктор искусствоведения, доцент Национальной академии руководящих кадров культуры и искусств

Художественный образ в контексте культурологической герменевтики

Цель - выявить особенности интерпретации художественного образа в произведениях современного искусства в контексте культурологической герменевтики. Методология работы основана на междисциплинарном подходе - «культурологической герменевтике», обогащенном методами аналитической психологии, структурализма, постструктурализма. Научная новизна работы заключается в анализе художественного образа в работах современного искусства в контексте культурологической герменевтики. Выводы. Основываясь на анализе произведений современного искусства, обосновано, истолкование художественного образа имеет незамкнутость и неисчерпаемость интерпретаций соответственно принципам герменевтики. У каждого интерпретатора будет собственный подход к содержанию как нового текста, так и первоисточника. На примерах истолкования художественных образов в произведениях современного искусства подтверждено, что опыт автора имеет первостепенное значение. Раскрытие художественного образа связано с психологией восприятием и поэтому включает в себя эстетические критерии.

Ключевые слова: художественный образ, культурологическая герменевтика, психология, структурализм, постструктурализм, современное искусство.

Relevance of the research topic. The artistic image in the work of contemporary art often has its own history in the sense that it was once well-known and used repeatedly in different types of art. For example, the image of Carmen is in the novella, operas, ballets, feature films, reminiscences on all these genres and again in different genres. All these transformations are subject to the procedure for identifying different semantic layers in new contexts. Therefore, to ensure the perception of modern images in art, their analysis and interpretation, for their adequate understanding, the methods of culturological hermeneutics are used.

The development of new technical methods in contemporary creativity leads to new forms of analysis of the artistic text. Therefore, not only the use of the same themes known in the history of art, but also their interpretation in a new context, create an actual field for research.

The analyses of recent researches and publication. The interpretation of the nature of the texts is studied by R. Bart, M. Bakhtin, E. Cassirer, F. Schleiermacher, K. Jung who, in the context of culturological

(C) Afonina O., 2018 
hermeneutics, discovered the patterns of interpretation of the content of the work and the psychologically aesthetic understanding of the author's style. Ukrainian researchers dealing with problems of cultural hermeneutics are O. Kolesnik, V. Lichkovakh, O. Roshchenko, L. Shapovalova and others.

About the content of philosophical and poetic forms B. Akhmadulina wrote: "The formula encodes the essence of artistic creativity, which is "undoubtedly" valiant service of harmony, but the creator creates the harmony, and to understand it, one needs to understand the creator, those meanings and values, which he puts into a special, constructive and iconic aspect of the musical form, "encodes" in the musical text, carefully "covers" the inner faces of the musical form, in the world of his artistic images created by him» [1, $p$. 197]. Cultural hermeneutics provides decoding of the artistic image on the basis of analysis of various codes of the work and their re-thinking in a new context.

For example, French dancer and choreographer Roland Petit to the music of A. Vivaldi's concerts «The Seasons» made a choreographic composition (1984), in which the records of the ensemble I. Muzychi were used. The name "Seasons» is a cultural and historical tradition, coming from: concerts of A.Vivaldi; Haydn's oratorio by the libretto of Baron Godfried van Sweeten on the basis of the poem by James Thomson (1801), the piano cycle by P. Tchaikovsky; less well-known opuses entitled "The Seasons» - the ballet of Marius Petipa on the music of A. Glazunov (1900) of the ballet of Mers Cunningham to the music of John Cage (1947). This storyline attracts many ballet makers, in particular, Konstantin Sergeev (1974) and Jerome Robbins (1979) for the music of Giuseppe Verdi. In the XXI century several more musical versions of the same ballet productions appeared: composer V. Martynov (2013) and choreographic cycle of composer G. Akhinyan (2014). All the mentioned works with corresponding symbolic images have their own unique decoding system in the foreshortening of cultural hermeneutics.

The author's inclination has the theme «Seasons» in the work of modern Ukrainian composer Zoltan Almashi Concerto grosso No 4 for violin solo and chamber orchestra. Composition-dedication to the wellknown Ukrainian violinist Bogdan Pivnenko has nine parts, which, according to the author, is connected with his sensations of the Ukrainian times of the year.

January here is a «Festive Song» with a melody of the romantic era, which transmits the mood of the Christmas holidays. Next month - February - «Valentine's Day Wallet» is a celebration of the event in the rhythms of dance. Part begins with an introduction, after which you expect development, and it breaks, and begins a triptych called «Spring». The "Thaw» (March) is rhythmically demonstrated by the entire orchestra, knocking, roaring, testifying to the coming of the spring. Solo parts with spring motives supported by the violin. The audience has associations with the symphony J. Haydn's "Children's», where the composer used tools from children's games.

The fourth part of Germination (April) and the fifth «Water Flowing and Flowering Gardens» (May) convey the state of the movement of nature and soul, emotionally painted by various feelings and their transformations. There are certain allusions to N. Rimsky-Korsakov's «Snow Maiden» motives or P. Tchaikovsky's "Times of the Year», but they are more likely to be "a lot of music" on the ears, and these allusions are more likely to be the «intonational dictionary of the era» by B. Asafiev or psychological archetypes of D. Kirnarskaya.

The diptych «Summer» is revealed in the «nostalgic dialogue» (June) and «Very fast» (July-August). Such a difference in mood appeals to the idea of development in the musical Viennese classics: slowly-fast, which creates dynamism in the disclosure of content. "Very fast» begins and ends with intonations of the cuckoo's predictions. The middle - jazz-romantic, even elegant, - tells about the short-term and such boundless beauty of feelings in the summer.

The eighth part of «Autumn» is represented by a state that evokes a feeling of irreversibility of time, philosophical reflections that are amplified by the repetition of the same motif in the violin and the roll call with low piano registers. It reminds both folklore intonations, and music of last decades with monotonous repetitions of phrases of text and music.

The last part of the work «The First Snow» (December) sets up emotional reboots: the symbol of the first snow as the arrival of winter and cold, but also the approach of holidays in January and February.

Zoltan Almashi in his comments to the work forms a sense of humour in the listeners in relation to the very well-known title "The Seasons», a sense of co-authorship in relation to those works that have the same names. Actually the composer forces all to reconsider their attitude to the whole structure of the work and in general to the seasons in nature in accordance with the place of residence. As the composer explains, if we lived beyond the Arctic coast, then we would have two seasons - bright and dark, and in our time zone, in his opinion, there are precisely such times of the year that they are, and so their names and contents are conditioned. This work brings listeners closer to modern being («Waltz for Valentine's Day», «Festive Song»).

Thus, in order to disclose the process of interpreting the work of Z. Almashi in the culturological expanse of modern art, we rely on the tradition of the heuristic potential of hermeneutics $V$. Dilthey and F. Schleiermacher. The message of the composer carries much more information than the author expected. In addition, to decipher the images of a new work with such a replicated name, we resort to the methodology of analytical psychology. This makes the composer himself to appeal to the performers and listeners in his comments. 
Postmodernism is characterized by a psychologized approach of classical hermeneutics. Otherwise how can you analyse the works of professional composer and artist Alexei Shmurak and his works «Little Tragedies». When during the performance on the stage there is a table, a chair, and A. Shmurak himself sits and plays with jewellery, which is in a tray for eggs. Outside the capacity for eggs, looking at the audience, the children's toy is seated and the "play" is called "This is a cat». For seven minutes, the author is looking at the score and various actions (whistling, knocking in different rhythms, with varying intensity and with the use of household items) playing «tragic events» that are going through the so-called cat. The means of creativity in the performance is the stage performance of the author, who assumes the role of the actor and represents actions that have a direct influence on the consciousness and unconscious reactions of the viewer. Under the title "Little Tragedies», there are certain allusions to the work of A. Pushkin, but with ironic processing of the established images of classics, known content, tragic heroes. The works in the series "Small Tragedies 1, 2» by A. Shmurak consist of content that generates itself and works autonomously for new content - often with the help of the author's movements not related to music (although the work is marked as musical and presented in the hall Union of Composers of Ukraine). The depth of Pushkin's texts is replaced by superficiality and rhizome. Deleuze and Guattari use these concepts, which oppose linear invariance and affirm the plurality of representations and transformations.

The nature of A. Shmurak's music and lyrics is associated with American experimental art and the works of Kenneth Gaburi. For example, with the work of K. Gaburi «Minim Telling - One Two, Three» (1973) with the speech and body of the performer. Shmurak also works as an author-performer and experiments with non-musical accessories, language, author's texts, noise effects and sound-imaged elements. It reminds fantastic examples of electronic and acoustic music with the usual Gordon Mammy's saw. This is also a kind of «synthesis», but already at the level of hybrid forms, methods and means of musical texts.

In this work of the author we are dealing with the creation of the Shmurak opus «Small Tragedies 1, 2» and its interpretation rather not as a scientific form of knowledge (G.-G. Gadamer), but as a game disclosure of the semantic possibilities of the work.

Analysing the work of the modern Ukrainian composer Sergei Zazhityko, the most famous M. Heidegger's maxims of language as the home of culture and human being are mostly recalled. The work of art is defined by M. Heidegger as «the message of being». The original theory of the creative act behind M. Heidegger can be traced in the work of S. Zazhityko "The solitary sail is white».

Although other works of the composer are characterized by a situation of altering familiar verse lines. At the same time, they reveal content that reaches absurdity, parody or grotesque. Such a musical work is a monologue with a dancing for the reader, tambourine, violin, bayan, mandolin, episodic baritone and other sounds. The work «Nestor Batyuk» (2000) is also indicative, where the composer plays on M. Lermontov's poem "Alone white sail», using only his first lines. In the composition it sounds like this: the reader says "The sail grows white», then it beats into the tambourine, the speed of recitation accelerates further, an absurd patter with rhythmic accompaniment of the tambourine arises. At the culmination, the line "white sail ...» again sounds in the hall and therefore, the composer shows that the hall supported his work, having attached to the action. The Lermontov's poem also appears as the code for interpreting, and especially the line «the sail grows white ...». The verb text has turned into an instrumental theatre.

According to M. Heidegger's theory, language dominates in the work. For the listener in S. Zazhityko's work, the listener really has a feeling that the composer was struck by the poet's phrase. It was the speech principle that brought the composer information to create a new opus. The composer as the «messenger of life» designed it into an artistic form.

According to M. Heidegger, the poetic work is the creativity of the language. For Zazhityko, Lermontov's poetic work became such a creativity of the language. Moreover, already its semantics can be characterized through author's design and poetic text.

From the elements of theatre, the composer used the movements of the instrumentalists, their repeated permutation, the replacement of instruments, an expressive acting game, along with an unusual play on instruments - accordion, tambourine, violin. The protagonist reads the revised M. Lermontov's verse, what helps another performer-musician, who creates an atmosphere of excitement. The whole process of action that takes place on the stage - play on a tambourine and accordion, noise sounds (wind, storms, screams) - causes a feeling of unreality of what is happening, it's some inadequacy in relation to the famous poetic text.

The quote in the form of lines of the poem by M. Lermontov over the course of time has already become a short program of the poet's creativity and now deciphers the content of the new work «Nestor Batyuk» by S. Zazhityko.

The metaphorical world according to Heidegger belongs to the author and forms the semantics of openness for the listener - in this example, Zazhityko's opus. But there is a lot of mystery and hidden meaning for both listeners and the author of the new work. This Gaydegger interprets as an integral part of the meanings that language carries - meanings that are not subject to the will of the author.

The composer not only uses someone else's verbal form for a musical work, but with its help represents the essence of his own composition, which is due to the imposition on the old text of a new figurative content with a new composition structure. In addition, the poem by M. Lermontov becomes an «advertise- 
ment» for the musical work of S. Zazhityko, which causes emotionally - evaluative and comic-shaped reactions among viewers and listeners. From history, we remember that in the «lon» hermeneutic - interpreter interpreter of the messages of the gods - they called poets. Therefore, the interpretation of Lermontov's poetic text in the musical improvisation of Zazhityko remains open and its interpretation can be inexhaustible. In addition, each interpreter will have his own approach to translating the content of the new text, which in turn will be another interpretation of the original poetic text in artistic criticism.

The Ukrainian researcher of the interpretation of artistic creativity Elena Kolesnik draws attention to a peculiar catalogue of conditional synonyms of the psychological - visionary type of personality that L. Pliushch has done: sentimentalism, idealism, Platonism, Dionysism, Prometheism, dynamism, extremism, syntheticism, rationalism, introversion, schizotemism. Therefore, when researching creativity of «psychologist» creators, it is necessary to pay attention to the external context - biographical, sociocultural, artistic, scientific, philosophical [2, 12].

As an example we can take the works of the modern composer Murat Kabardokov. His work «The First Dance» combine oriental and at the same time western musical intonations. Here the melody on the pentatonic with characteristic repetitions creates meditation and melodic-harmonious development of a purely European tradition. Meditative-melancholic romantic work, and according to the gradation of D. Kirnarskay - communicative archetype of «meditation» - sets the listener to a dialogical dialogue in the style of talking with oneself, or communicating a person through prayer with the deity.

In another work by composer M. Kabardov «Basso ostinato» (for a string quartet), the quiet sonority and infinity of the non-accented melodic lines with multivariate repetitions is blurred by jazz intonations. Although the work begins with allusions to the Bach prelude C-dur from Volume I of the «Well-Tempered Clavier». The eclectic combination of jazz intonations, which tend more towards the archetype «scream», being reproduced in the oldest folklore samples, and the meditativeness of the eastern melody create two opposite images - meditation and active action, which complement each other and represent the European traditions of melodic development. Semiotic uncertainty and fragmentation create a textual openness that determines the duality of the idea. The original and at the same time allusion of final episode of the whole work, when all the musicians in turn leave the stage, as in I. Haydn's "Farewell Symphony», causes a lot of emotions, like those who are familiar with the classics (Haydn's work), and in those, who see this composition move for the first time. Thus, the creator-«psychologist» is the translator of the ideas of time and space.

To clarify the artistic image, the Ukrainian philosopher-aesthetician, culturologist, poetess and writer V. Sukhantseva uses purely musical terminology, where the triad «language - text - understanding», throughout history from the early musical archaic in the oral tradition to modern composition exists as information, which is expressed and transmitted with the help of a set of specific musical means - intonations, rhythms, harmony, etc. [4, p. 100].

The works of Kabardokov reflect the essence of the concept of the receptive aesthetics of $H$.- $R$. Yaussa, which is associated primarily with receptive-historical research. Perceptions of artistic images of Kabardokov's works reflect the development of the aesthetic experience of the recipient.

Out of the five levels of the structure of the perception of the art of Yauss (associative, admiral, sympathetic, cathartic and ironic) for interpretation of the images of Vlad Troitsky's collective opera Coriolanus, two are more suitable: associative and ironic. They reflect in the process of perception and interpretation of images the «horizon of expectation» and «aesthetic distance» in relation to the original source. Interpretation or the hermeneutics of Shakespeare's images «Coriolanus» in the collective opera the famous modern Ukrainian director Vlad Troitsky directs spectators and listeners to co-authorship, to the dialogue «authorrecipient». The tragedy of Shakespeare was embodied in the improvisations of twelve performers. Prior to that, Troitsky was already developing another opera performance with a reminiscent nature: the opera Dead City, based on the novel The Dead Bruges by the famous Belgian writer Georges Rodenbach (1920, the production was held in Cologne and Hamburg). The author of the music of the opera "The Dead City» was an Austrian composer and pianist, the author of music for films - Erik Wolfgang Korngold. This work of Vlad Troitsky (2012) was quite ambitious - with chorus, soloists, an expanded composition of the symphony orchestra for 100 people. The image of the dead city on the stage was represented by projections of faceless buildings, imposed on the orchestra, there were two floors in the background of the scene. The space between the audience and the orchestra was filled with gravestones and crosses, people in black clothes with suitcases and coffins.

The new work of V. Troitsky «Coriolanus» as an opera-synthetic improvisation with Ukrainian folklore, military rhythmic intonation, church motifs, modern arrangements in reggae style represents an endless text. This applies to the update of the plot, and images, and musical and stage design. The party of Virgil is full of a number of quotes, albeit with changes (Netherlands anti-war protest song of the end of the 18th century with «Hurroo Hurroo» repetitions, the Syrian chant «Christ is Risen», ornamented with eastern melismatics, a lullaby from Nina's Matvienko repertoire "I rocked a little girl»). Quite uncommonly quoted is Shakespeare's 36th sonnet - «Let me confess that we two must be twain» in the love duet of Virgil and Caius Marcia [3].

From the point of view of the interaction of individual arts, as in most European theaters, in the scenography of the opera, the minimalist art of scenery is overlapped by the unorthodox stage costumes. The 
formulation of Troitsky is no exception. The main characters (baritones, bass, soprano) in the spectrum are dressed in dark raincoats painted with red stripes around the eyes and black around the mouth. Spatially the performers are located in different parts of the scene, the electronics engineer was put separately. The harpsichord and piano were placed tet-a-tet, facing each other. All the opera was more like an ancient Greek play or oratorio. Deepening the synthesis of the arts, the French choreographer Murad Mersouki combined dance, circus tricks and theater with mapping (pseudo-three-dimensional projection) «PIXEL. Creation 2014 Compagnie Käfig».

Lyric culmination of the operatic work of V. Troitsky was the ensemble of musical snuff-box and cello, accompanied by the love duet of Virgil and Kaya Marcia. All scenic performances were supplemented with a video series. As once the French composer D. Millau kept up to date, using in his operas and ballets a lot of «everyday» music that sounded around, and V. Troitsky transformed Miserere by K. Monteverdi. Monteverdi's music in the opera performance of Troitsky has acquired signs of reggae, tango, something like folk tunes. Such musical reminiscences in the opera act as communicative links, confirming the hypothesis of post-structuralism that the world is an endless text.

Conclusions. Based on the analysis of works of contemporary art, it is revealed that the interpretation of the artistic image remains open and inexhaustible, according to the principles of hermeneutics. Each interpreter will have his own approach to translating the content of the new text, which in turn will be another interpretation of the original text in art criticism. It is substantiated that the author's experience has an primary importance for revealing the artistic image and content of the work. Disclosure of the artistic image is associated with the perception and therefore includes the principles of the receptive aesthetics.

The interpretation of the artistic image in the context of culturological hermeneutics is a promising direction in art history.

\section{תimepamypa}

1. Ахмадулина Б. А. Миг бытия. Москва: Аграфр, 1997. 304 с.

2. Колесник О. С. Феномен інтерпретації в художній культурі: монографія. Київ: НАКККіМ, 2014. 265 с.

3. Морозова Л. Состояние Шекспира URL: https://lb.ua/culture/2014/ 12/02/-287972_ sostoyanie_shekspira.html (дата обращения: 18.09.17).

4. Суханцева В. К. Музыка как мир человека (От идеи Вселенной - к философрии музыки). Киев: Факт, 2000. 176 c.

5. In Memoriam. Ханс-Роберт Яусс // Новое литературное обозрение, 1997, № 25. С. 131 - 132.

\section{References}

1. Akhmadulina B. A (1997). The moment of existence. Moscow: Agraf, [in Russian]. Ukrainian].

2. Kolesnik O. S. (2014). Phenomenon of Interpretation in Artistic Culture: Monograph. Kiev: NAKKKiM [in

3. Morozova L. The state of Shakespeare URL: https://lb.ua/culture/2014/ 12/02 / -287972_ sostoyanie_shekspira.html (date of circulation: 18.09.17) [in Ukrainian].

4. Suhantseva V. K (2000). Music as the world of man (From the idea of the universe - to the philosophy of music). Kiev: Fact [in Russian].

5. In Memoriam. Hans-Robert Yauss (1997) // New Literary Review, 1997, No. 25 [in English].

Стаття надійшла до редакції 21.06.2018 p. 